\title{
DRAMA TO GO! Hints and hands-on activities for the classroom
}

\author{
Michaela Sambanis, Delil Baran, Kimon Beltrop, Lisa \\ Grabert, Janina Knorr-Dadfar, Josephin März, Andrea \\ Schneider, Frank Splitt Katharina Wonschik
}

\begin{abstract}
Drama to go! provides English language teachers with a creative compilation of drama activities based on theoretical reflections as well as findings from neuroscience, psychology, and drama pedagogy. Designed as compact printables, the drama activities are ready to be slipped into the teacher's pocket, thus becoming drama to go.
\end{abstract}

\section{Introduction}

We are a group of English philology trainee teachers enrolled in a Master of Education programme at the Freie Universität Berlin, who participated in a seminar on drama in the foreign language classroom taught by Prof. Dr. Michaela Sambanis (chair of English didactics) in the winter term 2012/2013. In the course of the semester, we came across many inspiring ideas in already existing publications on drama in the classroom such as Tselikas 1999, Elena 2011. However, as future English teachers we were eager to find hands-on material for the classroom allowing flexibility in use, bringing more creativity to our teaching, and providing us with the essential theoretical as well as practical information to keep us informed and well-oriented. Inspired by different articles, manuals etc., we finally decided to create our own material for the foreign language classroom including classic examples as well as new drama impulses. We opted for a mode of presentation that we feel would be useful and easily accessible. As compact printables, the drama activities are ready to be slipped into the teacher's pocket, thus becoming drama to go (cf. section 3).

After this introductory paragraph, section 2 will provide some preliminary remarks on the use of drama in the classroom, including a definition, a short reflection on Flow-experiences and on the potential of so-called Sprachnotsituationen (cf. Tselikas, 1999: 39, 41). Furthermore, the section includes a brief insight into relevant studies with a glimpse at findings from neuroscience. 
Section 3 presents the drama activities categorized by their respective function (warm-up- , drama-, or cool-down activities) and verbal challenge, ranging from non-verbal to verbal. Section 4 provides the conclusion and section 5 indicates the references.

\section{Why drama?}

To answer the question why drama might be a useful tool and, aside from that, a source of inspiration to teachers and learners alike, a definition of the term drama in education, as we understand it with regard to the foreign language classroom, seems relevant at this point. In a nutshell, "drama in education [...] uses the means of theater for pedagogical/educational use, i.e., to initiate or enhance learning processes" (Ronke 2005: 21). At the same time, drama in education goes beyond the pure utilitarian aspect as it opens doors and creates opportunities of aesthetic, (inter-)cultural, personal, and social value. In contrast to the more product-orientated approach of theatre in education, drama in education emphasizes process-orientation, i.e. students do not necessarily have to perform on stage (cf. Butzkamm 2012: 14). It is not the main goal to stage a play, but rather to establish the getting into different roles and scenes as a basic and important component of teaching and learning in the EFL-classroom As will be seen in the following, drama activities can be fascinating to the point that the participants get completely absorbed .

\subsection{Flow}

Flow, defined as a state of optimal experience, can be regarded as a desirable frame of mind, a powerful enabler of effective learning. According to the Hungarian psychologist Csikszentmihalyi, known for his work on creativity and happiness, Flow is "a state of mind or a state of experience when we are totally involved in what we are doing" (cf. interview on www.youtube.com/watch?v=JjliwSJGDiU). In this state, people value the activity at hand for its own sake rather than for any extrinsic rewards. Luckily, most people know this phenomenon from their own experience, i.e. from situations, in which they feel completely absorbed and satisfied by their activity, confident, motivated, happy, at ease and, in some cases, strongly related to others, too (cf. Csikszentmihalyi 1975: 13). Getting into the Flow means getting absorbed, being in the Flow means feeling energized, motivated to carry on, and blocking everything else out. In short, Flow comprises ideal conditions for learning.

This begs the question of how such optimal experiences can be triggered in the EFL-classroom. With reference to Sachser's work (2009), we argue that drama activities may provide the necessary conditions to promote Flow in the classroom. Drawing on Csikszentmihalyi (1990: 71), Sachser lists eight components (2009: 49-51) that are characteristic for optimal experience: 
- Passung zwischen Anforderung und Fähigkeit - match between challenge and skills;

- Klare Ziele und Rückmeldungen - clear definition of goals, clear feedback;

- Kontrolle - a sense of control

- Konzentration auf ein eingeschränktes Stimulusfeld - intense concentration on a limited situation, focus on one activity

- Veränderte Zeitwahrnehmung - different perception of time

- Zusammenfluss von Handeln und Bewusstsein und Selbstvergessenheit - self-forgetfulness as a result of the absorption by the ongoing activity, focus on the Flow-experience, blocking out of distractors

- Die autotelische Erfahrung - autotelic experience, no desire of external reward

- Die Steigerung des Selbst - going beyond the limits of current knowledge and competences, excelling

Remarkably, many actors name these characteristics when asked to describe their state and emotions during performances (cf. Sachser 2009: 206-225).

What consequences can be drawn for the use of drama in the EFL-classroom? First of all, students should feel comfortable and safe as if they were in a sheltered place (cf. Sachser, 2009: 303) when participating in a drama activity. Furthermore, as trust, patience, respectful behaviour and social stability among the participants are important factors of influence, agreements should be made between all students (cf. drama contract, section 3). Before drama activities, students should become energized and focused by suitable warming-up exercises or classroom rituals to get into a frame of mind and state of activity that might promote Flow-experiences.

\subsection{Sprachnotsituationen}

Apart from Flow-experiences as powerful, emotionally rich, and intellectually stimulating experiences, what are other possible benefits of drama? One benefit is, without doubt, the creation of so-called Sprachnotsituationen (cf. Tselikas 1999: 41) in the course of drama activities. The term translates as language emergency situations and relates to communicative situations in which a foreign language learner has to spontaneously become communicatively active. Becoming aware of the discrepancy between his/her current level of proficiency and the demands of the situation, the learner experiences uncertainty, but at the same time wants to face the challenge. Such gaps can be bridged verbally as well as non-verbally, alone or collaboratively. The carefully managed exposure to Sprachnotsituationen in a classroom-environment where 
students feel safe and at ease can help learners to overcome inhibitions. In this context, Bonnet \& Küppers (2011: 42) point out that Sprachnotsituationen possess great similarities to situations that can be encountered in everyday life. Mastering these settings in the classroom prepares students for real life situations. Besides, Sprachnotsituationen represent an opportunity to positively challenge the students, to train their communication as well as their improvisation skills, and to involve them as whole personalities, i.e. not only cognitively.

\subsection{Evidence-based research}

There are a number of already existing studies on single aspects of drama activities or different programmes (cf. Scenario 1, 2012). For instance, Hille, Sambanis et al. (2010) with their evaluation of a drama-based approach called Szenisches Lernen/Scenic Learning as well as Sambanis (2011), and Sambanis \& Speck (2010) provide evidence for the positive effects of body-movements especially on the acquisition and retention of vocabulary. As movements constitute an important element of many drama activities (for a brief discussion cf. Kessler 2008: 35-39), these results seem noteworthy.

Additionally, Domkowsky's study, carried out in Darstellendes Spiel, a drama subject taught in German in Berlin, found slightly beneficial effects of drama activities on several relevant factors that influence students' success and well-being (cf. Domkowsky \& Walter 2012), namely achievement motivation, extraversion and openness.

From a neuroscientific point of view, Spitzer (2009) concludes that dramaor theater-based approaches provide ideal conditions for learning, in a manner of speaking, "brain-friendly" conditions:
Aus dem, was wir über die Gehirnentwicklung wissen und ein paar weni- gen durchaus plausiblen zusätzlichen Annahmen folgt damit, dass man kaum etwas Besseres mit jungen Menschen tun kann als mit ihnen Thea- ter zu spielen." (Spitzer 2009: 102)

From what we know about the human brain and its development we have reasons to believe that drama and theatre in education are powerful, if not ideal tools.

\subsection{A glimpse at neuroscience}

In order to explain the effects of drama on learning processes, we will now give an overview over some relevant findings from neuroscience. For instance, a study by Kiefer (2007) has shown that the combination of linguistic units and body-movements, which are performed by the learner himself/herself, leads to a better retention of new entities. In addition to that, a study by Macedonia et al. (2011), which dealt with the question if random movements have the same effect on memory as meaningful ones, has shown that the latter ones have 
a very good effect on memory while random gestures are rather perceived as incongruent by the brain, which will therefore try to obstruct the information. Pulvermüller (2005: 576) explains this phenomenon by pointing out that frequently co-activated neurons strengthen their mutual connection, stating that "it is likely that the cortical systems for language and action develop specific links between each other whenever actions correlate with specific language processes". As a result, "understanding language means relating language to one's own actions [...]" (Pulvermüller, 2005: 581). These findings can be applied to the explanation of the success of drama activities, as in drama, linguistic entities will always be accompanied by meaningful gestures, which support the brain in the process of remembering the new information. The significance of the linguistic information is very important as the brain needs to filter out the most relevant aspects of the constant flow of new impressions received by the sensory channels and transmitted to the brain (cf. Sambanis, 2010: 22). Specific centers in the brain then have to separate relevant from irrelevant information using novelty, uniqueness, clarity, emotional significance etc. as filters. Drama activities may support this filtering process by attracting and directing the attention of the learner.

Another study carried out by Erk, Spitzer et al. (2003) revealed that, in fact, positive emotions boost the storage of words. Negative and positive emotions lead to different patterns of activation in the brain. Depending on the respective brain activation pattern, learning can be more or less successful. The study illustrates that learning is not only influenced by cognitive factors but equally by emotions. These findings can be connected to the positive impact of drama in two different ways. First of all, when drama activities are successfully established in the classroom, the learning environment can be relaxed and merry, preventing destructive forms of stress while fostering positive emotions when the students enjoy the activities. Secondly, emotions can be attached to linguistic units directly within drama activities, for example, when students are asked to get into a role or merely read out a line in a certain tone with a specific underlying emotion. While improvising a scene, for example, the students take on the emotion, thus connecting language to emotions, which will again strengthen the linking process in their brains. In addition to the link between language and emotions, the student makes also use of body-movements, facial expressions and gestures while improvising or acting. This leads to an involvement of the student's whole person and allows multisensory, holistic learning, i.e. learning with head, heart, and hand.

In the field of education the concept of head, heart, and hand was first introduced by the Swiss pedagogue Pestalozzi (1746-1827; cf. Monyer, 2010: 14). Prior to that, Comenius (1592-1670) had already suggested that learning should involve as many senses as possible. Referring to Comenius, Spitzer concludes: "Und wenn etwas durch verschiedene Sinne aufgenommen wird, soll es den verschiedenen zugleich vorgesetzt werden." (Spitzer, 2010:123). If information can be processed by multiple senses, as would be desirable, it has to be presented accordingly, i.e. in a multimodal way. Without 
doubt, drama supports multisensory learning. As Schewe (1993: 8) later put it in the context of foreign language education: „Im dramapädagogischen Fremdsprachenunterricht wird mit Kopf, Herz, Hand und Fuß gelernt und gelehrt!“

\section{Window of practice}

The relevance of a non-threatening atmosphere has already been pointed out in section 2. Fear hinders creativity (cf. Hüther 2012: 79), figuratively speaking, it keeps students from spreading their wings. As a famous saying attributed to Goethe (1749-1832) goes, children need wings and roots, i.e. a secure environment that does not hinder the child's need of autonomy. Adapted to the drama-oriented classroom, roots and wings may be defined as a sense of belonging to a classroom community that welcomes diversity, allows trial and error and fosters productive ideas. In this respect, the afore-mentioned drama contract can be used as a tool to raise awareness of what it means and what it takes to establish and to cultivate a suitable, drama-friendly atmosphere in the classroom (for further concretion cf. Elena 2011: 32-33).

Also, the structure of drama sequences seems of relevance. According to Tselikas (1999: 44), it is important to use three phases: warm-up, drama and cool-down. Referring to this, the following section presents the drama activities categorized by these three phases, i.e. by their respective function, and, in addition to that, by the verbal challenge, ranging from verbal to non-verbal. Facing the impossibility to cover all grades and proficiency levels with the selected activities, we focused on the intermediate. Nonetheless, the printables provide further suggestions, alternatives and modifications that can be used to vary or differentiate.

\subsection{Warm-up phase-setting the scene}

The main function of this first phase is to welcome students, to motivate, relax, and energize them. Using movements and different exercises, the students increase their self-perception and concentration during this phase:

Eine gute Aufwärmung lohnt sich, sie ist wie Dünger, der einen guten Boden schafft, aus dem Ideen, Fantasie, sprachliches Material wachsen können. (Tselikas 1999: 61)

Furthermore, the warm-up phase allows students to step out of the classroom into an imaginary situation. Many warm-up exercises focus on the development of group awareness and group dynamics:

The goal is to create positive group dynamics - a low affective filter within the group, as well as a comfortable, safe, and supportive atmosphere that promotes trust, mutual respect, and a feeling of belonging. (Ronke 2005: 217) 


\subsection{Drama Phase-being part of the scene}

In this phase, the students take on different roles, step into someone else's shoes, think about storylines, sequence actions, create scenes etc. The forms can be varied, ranging from frozen-images or pantomime to attempts of dramatic reading, enactment or spontaneous improvisations. To increase motivation and concentration, it is important to use a variety of drama techniques, to work on different texts and topics.

\subsection{Cool-down Phase-stepping out of the scene}

Just like warm-up activities, cool-down activities are of importance to complete a drama lesson. During the actual drama activities, the students should profit from the possibility to take on roles instead of acting as themselves. As already mentioned the drama experience can be very intense and absorbing. Therefore, it seems crucial to thoughtfully plan the transition back to reality. This is where cool-down activities come into play: they help the students to relax and they present an explicit ending to the drama phase encouraging students to make their transition from drama mode back into real-life mode. Having stepped out of their roles, the students can reflect upon the drama activity and may share with the classroom community their experiences, impressions as well as learning outcomes.

\section{AS IF - Warm-Up Activity}

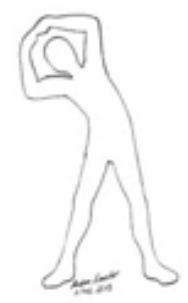

verbal / non-verbal

Social form:

- class

Aim:

- warming up

- beginning a drama lesson 
Material / Props:

- little pieces of paper, pen

Duration:

- depending on the number of students, about 5 minutes

Procedure:

Every student gets two cards. One card names an activity, e.g. playing the guitar, the other one an adverb, e.g. aggressively. The student combines both elements and acts out. The other students guess.

Variation:

Card one indicates a mood (e.g. angry, sad, in love); card two contains a sentence (e.g. God save the Queen). Instead of acting out, the students read the sentence out loud giving it the corresponding tone, facial expression etc.

\section{ZIP - Warm-Up Activity}

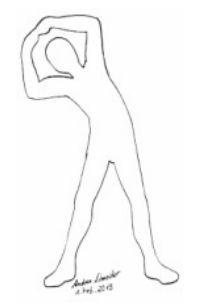

verbal

Social form:

- class

Aim:

- warming up

- beginning a drama lesson

Material / Props:

- none

Duration:

- less than 5 minutes 
Source:

- Wright et al. (1979): 87.

Procedure:

First, the class chooses a taboo-number, e.g. four. Then, the students count for example from 1 to 10 and from 10 to 1 , carefully avoiding the taboo-number: student 1: one / student 2: two / student 3: three / student 4: zip / etc.

Variation:

To make it a little more complicated, several numbers can be banned and replaced by zip. All numbers that include a taboo-number $(4,14,24 \ldots)$ can be replaced.

\section{REMEMBER THAT DAY!? - Warm-Up Activity}

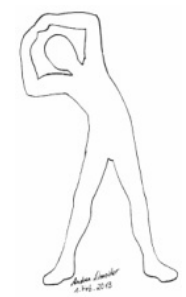

verbal

Social form:

- class

Aim:

- warming up

- beginning a drama lesson

Material / Props:

- none

Duration:

- 10 minutes 
Procedure:

This warm-up works like the game I packed my suitcase but with activities and the matching movements. The first player thinks of an activity and says for example: "After I woke up, I stretched." ("stretching*)"

The next student repeats the sentence together with the movement and adds something: "After I woke up, I stretched ("stretching*). Then, I danced to the bathroom ("dancing*)."

Remember that Day?! continues until someone makes a mistake, cannot come up with another activity or inverts the order.

Variation:

The activities could include the students' names: “...and then Tina stretched (*stretching*)".

\section{HEE, HA, HO! - Warm-Up Activity}

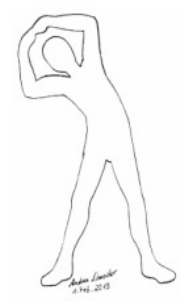

verbal

Social form:

- class

Aim:

- warming up

- beginning a drama lesson

Material / Props:

- none

Duration:

- less than 5 minutes

Source:

- inspired by Ann-Marleen Barth, Theater Strahl, Berlin 


\section{Procedure:}

Students stand in a circle facing the center. The game starts with three students (A, B, C) standing next to each other in the circle. Student A addresses the neighbour to his/her left (student B), uttering the syllable "Hee" accompanied by a hand gesture towards student B. Student B answers with "Ha" and an arm gesture. Then, student $C$ joins in. Together with student A, student $C$ turns towards student $B$ and wraps up the little three-part conversation by "Ho" accompanied by yet another hand gesture, e.g. an appreciative pointing gesture such as the thumbs up. The conversation starts over with student B taking on the role of student A, student $\mathrm{C}$ taking on the role of student $B$, plus the next player in the circle becoming student $C$.

\section{DESCRIBING A PICTURE - Drama Activity}

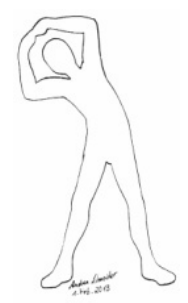

verbal

Social form:

- working in pairs

Aim:

- collaborating

- describing a picture

- training verbal communication skills

- instructing someone how to draw as true to the original as possible

Material / Props:

- a picture, pencil, sheet of paper

Duration:

- up to 12 minutes 
Procedure:

The students form tandems, sitting back to back. One of the students (A) is equipped with a picture, the other one with pencil and paper. Student A describes the picture to his/ her partner while the other one, who is neither allowed to peek over the shoulder nor to ask questions, tries to draw the picture based on the description. After five minutes, original and drawing are compared. The tandems can choose whether or not to show the result to the whole class.

Variation:

This activity can be performed by one couple in front of the whole class. To activate more students, however, the whole class may take part in the exercise as well. In this case, pairs of two students are working together.

\section{ALTERNATIVE ENDINGS - Drama Activity}

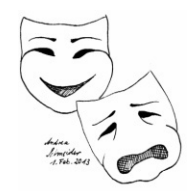

verbal

Social form:

- audience/class

Aim:

- training verbal communication skills

- training writing skills

- creating and continuing an ending to a story from classic literature

Material / Props:

- a story

Duration:

- up to 2 lessons

Procedure:

Students form groups of four to five. Using the style of a theatre script, they rewrite the ending of a story. To do so, they should try to stick as close as possible to the traits of the characters as suggested by the original story. The 
groups choose a mode of presentation (dramatic reading, radio play, shadow theatre etc.) for their text, and present their alternative endings in the plenum.

Variation:

This exercise can also be used as a class contest. In this case, the group with the best presentation or the group with the most interesting/creative/ realistic alternative ending wins.

\section{METAPHORS - Drama Activity}

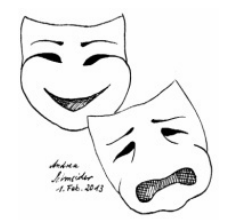

verbal / non-verbal

Social form:

- working in groups

Aim:

- training verbal and non-verbal communication skills

Material / Props:

- a board to draw on, worksheets with metaphors, coloured team-cards

Duration:

- 30 minutes

Procedure:

Divide the class into teams of five or six students. Each team receives a colour coded worksheet and an equally coloured team-card. The worksheet contains a list of metaphors, two (different for each group!) in bold print. The team decides which of the two to use for Guess what I'm drawing and which one to pantomime. The subsequent presentation phase is held in form of a contest in the plenum. While one team is presenting their drawing/pantomime, the others guess and confer in their teams. When they think they know the correct answer, they raise the colour coded team-card and tell the team's guess. If the answer is correct, the team scores a point.

Variation:

Instead of metaphors, use proverbs or fixed expressions 


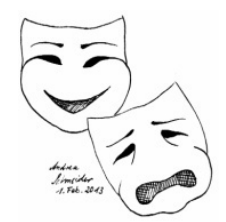

\section{STATUE THEATRE - Drama Activity}

$$
\text { non-verbal }
$$

Social form:

- working in groups

Aim:

- dramatic reflection on the topic

- working with current global topics/problems

- training creative writing skills

Material / Props:

- none

Duration:

- up to 1 lesson

Source:

- Elena (2011)

Procedure:

The students form groups of five. Every group has to think about a problem which they connect with the future. Topics could be war, poverty, global warming etc. Those problems will be collected on the board. After that, every group has to pick one topic from the list and present it as a freeze-frame image. Variation:

The presentation of the freeze-frame image could also be divided into three parts: 1. Reality What is the present situation? 2. Transition How can the problem be solved? 3. Ideal What should the future look like? Accordingly, the students present three different freeze-frame images.

SPONTANEOUS TALKING - CUTTING IN - Drama Activity 


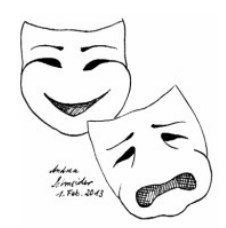

verbal

Social form:

- class/audience

Aim:

- training speaking skills

- training improvisation skills

- training social competence

Material / Props:

- none

Duration:

- up to 20 minutes

Source:

- Elena (2011)

Procedure:

Two students get "on stage". By spontaneously calling out, someone sets the situational frame for the actors (wedding, birthday party, etc.). They start improvising a scene. If one of the spectators has an idea about how to change the scene, he/she claps his/her hands and the two actors freeze while he/she joins the frozen tableau. Then, he/she gently touches one of the actor's shoulders and takes over his/her place. The replaced actor leaves the stage and joins the audience while the scene continues.

THE STONE'S FUNERAL ORATION OR EULOGY - Drama Activity

verbal

Social form: 


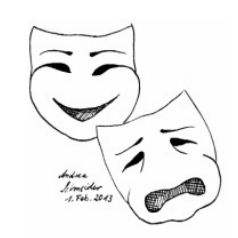

- presenters/Audience

Aim:

- training speaking skills

- training creative skills

- training writing skills

Material / Props:

- none

Duration:

- up to 10 minutes

Procedure:

Every student thinks of an object and prepares a short speech for his/her personal object. It might be a rubber, a mobile, a stone or something else. In the speech, the student expresses his/her feelings for the object, points out its relevance, its advantages etc. $\mathrm{He} /$ she may also tell anecdotes involving the object of his/her choice but without naming it. The class guesses what their classmate is talking about.

\section{COUNTING DOWN - Cooling-Down Activity}

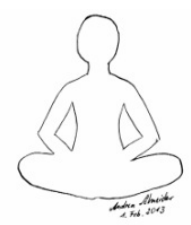

verbal

Social form:

- class 
Aim:

- counting down the numbers from ten to one with decreasing volume

- calming down, ending the drama-oriented phase

Material / Props:

- none

Duration:

- less than 5 minutes

Procedure:

Students are asked to count backwards from 10 to 1 with their eyes closed. While doing so, they should reduce the volume of their voices. Number 10 is spoken out loudly whereas the following numbers are spoken out with decreasing volume. Finally, number 1 should only be whispered.

STEPPING OUT OF A SNAPSHOT - Cool-Down Activity

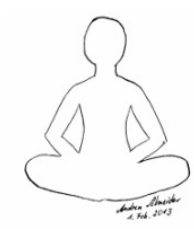

non-verbal

Social form:

- class

Aim:

- literally stepping out of one's role

- calming down, ending the drama-oriented phase

Material / Props:

- none

Duration:

- less than 5 minutes 
Procedure:

The students form a snapshot in which they present a character that they have played in the drama activity beforehand. One student then wanders around the sculpture and releases the students one by one, tapping them on the shoulder. If they are selected, they step out of the snapshot without talking and sneak back to their seats, thereby literally stepping out of their role and becoming themselves again.

\section{IMAGE ABOUT ME - Cool-Down Activity}

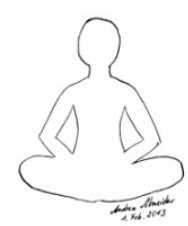

\section{verbal / non-verbal}

Social form:

- class / pair

Aim:

- calming down

- ending a drama lesson

- becoming aware of emotions during drama lessons

Material / Props:

- none

Duration:

- 5 minutes

Source:

- Cf. Ronke (2005), modified

Procedure:

Some volunteers create a frozen image showing their emotion during the lesson. The rest of the class has to interpret.

Variation:

This exercise could also be carried out in tandems to spare the students the exposure to more than one peer. 


\section{Conclusion}

This article set out to offer some theoretical considerations on drama in the EFL-classroom as well as a brief summary of relevant findings and to provide English language teachers with hands-on material on drama activities. We hope our compilation will prove effective in increasing concentration and creativity and will enrich classroom interaction. For further material please visit:

http://www.geisteswissenschaften.fu-berlin.de/we06/engdid/blick_in_ die_lehre/index.html.

\section{Bibliography}

Bonnet, Andreas; Küppers, Almut (2011): Wozu taugen kooperatives Lernen und Dramapädagogik? Vergleich zweier populärer Inszenierungsformen. In: Küppers, Almut et al. (eds.): Inszenierungen im Fremdsprachenunterricht: Grundlagen,Formen, Perspektiven. Braunschweig: Diesterweg, 32-52

Butzkamm, Wolfgang ${ }^{3}$ (2012): Lust zum Lehren, Lust zum Lernen: Eine neue Methodik für den Fremdsprachenunterricht. Tübingen: Narr Francke Attempto Csikszentmihalyi, Mihaly [1975] (2000): Das Flow-Erlebnis: Jenseits von Angst und Langeweile: im Tun aufgehen. Stuttgart: Klett-Cotta

Csikszentmihalyi, Mihaly (1990): Flow. The Psychology of Optimal Experience. New York: Harper Collins.

Csikszentmihalyi on flow: http://www - youtube.com/watch?v=JjIiwSJGDiU (last access Feb $6^{\text {th }}$ 2013)

Elena, Denise (2011): Dramapädagogik für Englisch in der Sekundarstufe. Buxtehude: AOL.

Domkowsky, Romi; Walter, Maik (2012): Was kann Theater? Ergebnisse empirischer Wirkungsforschung. In: Scenario 1, 103-126

Erk, Susanne; Kiefer, Markus; Spitzer, Manfred et al. (2003): Emotional context modulates subsequent memory effect. In: Neuroimage 18, 429-447

Hille, Katrin; Sambanis, Michaela et al. (2010): Szenisches Lernen im Fremdsprachenunterricht - die Evaluation eines Schulversuchs. In: Diskurs Kindheits- und Jugendforschung 3, 337-350.

Hüther, Gerald (2012): Die Freiheit ist ein Kind der Liebe. Freiburg: Kreuz Verlag

Kessler, Benedikt (2008): Interkulturelle Dramapädagogik. Dramatische Arbeit als Vehikel des interkulturellen Lernens im Fremdsprachenunterricht. Frankfurt a.M.: Lang

Kiefer, Markus et al. (2007): Experience-dependant plasticity of conceptual representations in human sensory-motor areas. In: Journal of Cognitive Neuroscience 19 (3), 525-542 
Macedonia, Manuela et al. (2011). The Impact of Iconic Gesture on Foreign Language Word Learning and its Neural Substrates. In: Human Brain Mapping 32, 982-998

Maley, Alan; Duff, Alan (2005): Drama Techniques: A Resource Book of Communication Activities for Language Teachers ( $3^{\text {rd }}$ edition). Cambridge: Cambridge University Press

Monyer, Yvonne (2010): Dramapädagogik im FremdsprachenunterrichtLernen durch Spielen. Heidelberg.

http://www. theaterwerkstattheidelberg.de/uploadverzeichnisse/ downloads/AA_Y_MonyerTP10-2.pdf (last access Feb 29 ${ }^{\text {th }}$ 2013)

Pulvermüller, Friedemann (2005): Brain mechanisms linking language and action. In: Nature 6, 576-582

Ronke, Astrid (2005): Wozu all das Theater? Drama and Theater as a Method for Foreign Language Teaching and Learning in Higher Education in the United States. (Dissertation TU Berlin) http://opus.kobv.de/tuberlin/volltexte/2005/1042/

Sambanis, Michaela (2010): Neurowissenschaftliche Reflexionen zum Fremdsprachenunterricht in der Grundschule. In: Altmayer, Melhorn et. al (eds.): Grenzen überschreiten: sprachlich - fachlich - kulturell.

Baltmannsweiler: Schneider, 15-27

Sambanis, Michaela; Speck, Alexandra (2010): Lernen in Bewegung: Effekte bewegungsgestützter Wortschatzarbeit auf der Primarstufe. In: Französisch heute 3, 111-115

Sambanis, Michaela (2011): Weniger stillsitzen, mehr lernen? - Effekte bewegungsbasierter Wortschatzarbeit auf der Primar- und Sekundarstufe. In: Schäfer, Patrick; Schowalter, Christine (eds.): In mediam linguam.

Mediensprache - Redewendungen-Sprachvermittlung.Landau: VEP, 365-376

Sachser, Dietmar (2009): Theaterspielflow. Über die Freude als Basis schöpferischen Theaterschaffens. Berlin: Alexander Verlag.

Schewe, Manfred (1993): Fremdsprache inszenieren. Zur Fundierung einer dramapädagogischen Lehr- und Lernpraxis. Oldenburg: Zentrum für pädagogische Berufspraxis

Spitzer, Manfred (2009): Kindertheater. Kreativität, Vorstellungen und Gehirnforschung. In: Nervenheilkunde 28, 97-102

Spitzer, Manfred (2010): Medizin für die Bildung - Ein Weg aus der Krise. Heidelberg: Spektrum

Tselikas, Elektra I. (1999): Dramapädagogik im Sprachunterricht. Zürich: Orell Füssli

Wright, Andrew; Betteridge, David; Buckby, Michael (1979): Games for Language Learning (3rd edition 2006). Cambridge: Cambridge University Press 